\title{
お客様指向の技術情報誌実現に向けた取り組み 一堀場製作所の場合一
}

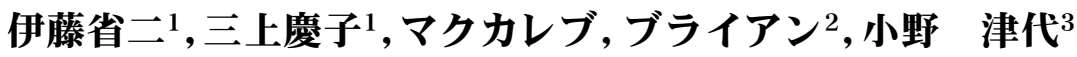

著者抄録 : 近年, 製造業が自社の技術力をPRすることは, ビジネス発展のために重要な広報活動 の1つとなっている。従来, 数多くのメーカが, 技報の発行を通して研究開発の成果や製品の技術 内容を紹介してきたが, 多様化・高速化する市場ニーズに十分には対応できていない。本稿では, 堀場製作所の技術情報誌Readoutの編集発行を例にして, より効果的でスピーディーな技術情報 サービスを実現するための課題と, ホリバの新しい取り組みを紹介する。技術者の技術情報入手 方法, Readoutの編集・制作工程, お客様への電子配信システムなどについて述べる。 キーワード : 技術情報サービス, 技報, 編集, 電子配信, 計測機器

\section{Actualization of customer-oriented technical bulletin at Horiba Ltd.}

\section{ITO Shoji', MIKAMI Keiko ${ }^{1}$, McCaleb, Brian² $^{2}$ ONO Natsuyo}

Author Abstract: In the recent years it has been significant PR activities that manufacturers do appeal their own technology or expertise to the outside world. It will surely get their business progressed. So far various manufacturers have introduced their R \& D results or new products through publications they issue, but those activities seem not enough for them to meet the needs of markets where diversification as well as rapid changes have occurred. Taking the technical bulletin titled "Readout" issued by Horiba Ltd. as a case the author describes how to actualize more effective and speedy technical information services, and how Horiba. has been tackling the new issues. How engineers get access to technical information they need, how to compile and make Readout, and electronic distribution system for its customers are also briefed.

Key words: technical information service, technical bulletin, editing, electronic distribution, analytical instruments

（情報管理 44 (8): 557-563）

\section{1.はじめに}

企業が発行する技報はここ 10 年間で大きく変 わつた。
それまでの技報は,メーカが自社の研究開発成果 を専門の研究者や技術者に紹介することが主な目 的であった。日立評論や東芝レビューなど大手企業 の技報は, レベル, 内容ともに充実しており, 学術

${ }^{1}$ (株) 堀場製作所 知的所有権部（干601-8510 京都府京都市南区吉祥院宮の東町2番地）

Tel. 075(313)8121 E-mail: ito-s@horiba.co.jp

${ }^{1}$ HORIBA, Ltd. (2, Kissyoin-miyanohigashi-cho, Minami-ku, Kyoto-shi, Kyoto, 601-8510)

${ }^{2}$ Conslting Professionals United (2603 Brookside Ave. Orange, CA 92867 USA)

Tel. (714) 974-2399 E-mail: bem@atdial.net

${ }^{3}$ (株)ダイテック 京都営業所（テ600-8218 京都府京都市下京区七条新町東八西境町163 洛西駅前第2ビル4F）

Tel.075(342)1088 E-mail: ono@daitecjp.com

${ }^{3}$ DAITEC, Ltd. (Rakusai-ekimae 2nd Bldg. 4F, 163, Shichijo-shinmachi-higashihairu Nishisakai-cho, Shimogyo-ku, Kyotoshi, Kyoto, 600-8218) 
雑誌としても高い評価を得ていた。一方で, 技報の 多くは,それぞれのお客様に限定的に配布されるた め, 官公庁の資料や学位論文と同様, 流通性のない いわゆる灰色文献として位置づけられてきた1)。 1990年代に入り, 日本の製造業をとりまく経済, 技術, そして社会環境は大きく変わり，技報もまた 大きく変わりつつある。あふれかえる情報の中か ら，お客様に自社の製品や技術をどのようにPRし， ご理解いただくかに主眼が置かれるようになって きた。そのためのキーワードが「お客様指向, 読者 指向」である。

\section{2. 技術情報の入手方法}

技術者が必要とする情報は, 研究開発の進渉に応 じて異なってくる。初期の企画段階では科学技術の 先端情報が, 開発目標を設定する段階では競合他社 の状況が, そして, 実際のモノ作りでは具体的な設 計データが必要となる。技報の編集者としては, 彼 らがどのような手段で, それらの情報を把握するか を知ることが重要である。そこで, 当社の開発技術 者たちに対してアンケート調査を実施した。

調査は,

(1) 先端情報調査
(2) 競合状況把握

(3) 設計データ収集

の各段階で,

○インターネット

業界・尃門誌

○学会・講演会

展示会

○対面調查

の, どのツールをよく利用しているかを, 順位付け する形で行った。

結果を図1に示すが，いずれの段階でも業界·専 門誌の利用頻度が最も高く,インターネットがこれ に続いている。業界・専門誌の割合が最も高い傾向 は, 中小企業庁が平成8年度に実施した企業の情報 化実態調査の結果 ${ }^{2}$ ともよく一致している。なお, インターネットの割合が大幅に高くなっているが, これはここ数年の急激なIT技術の進歩に合わせた， 当社の情報インフラがよく整備されていることに 起因するものと考えている。

あわせて実施した技報の利用状況に関するヒア リング調査によると, 技報は, 特定の業界や企業の 動向を把握するために大変有効なツールであるこ とが明らかになった。

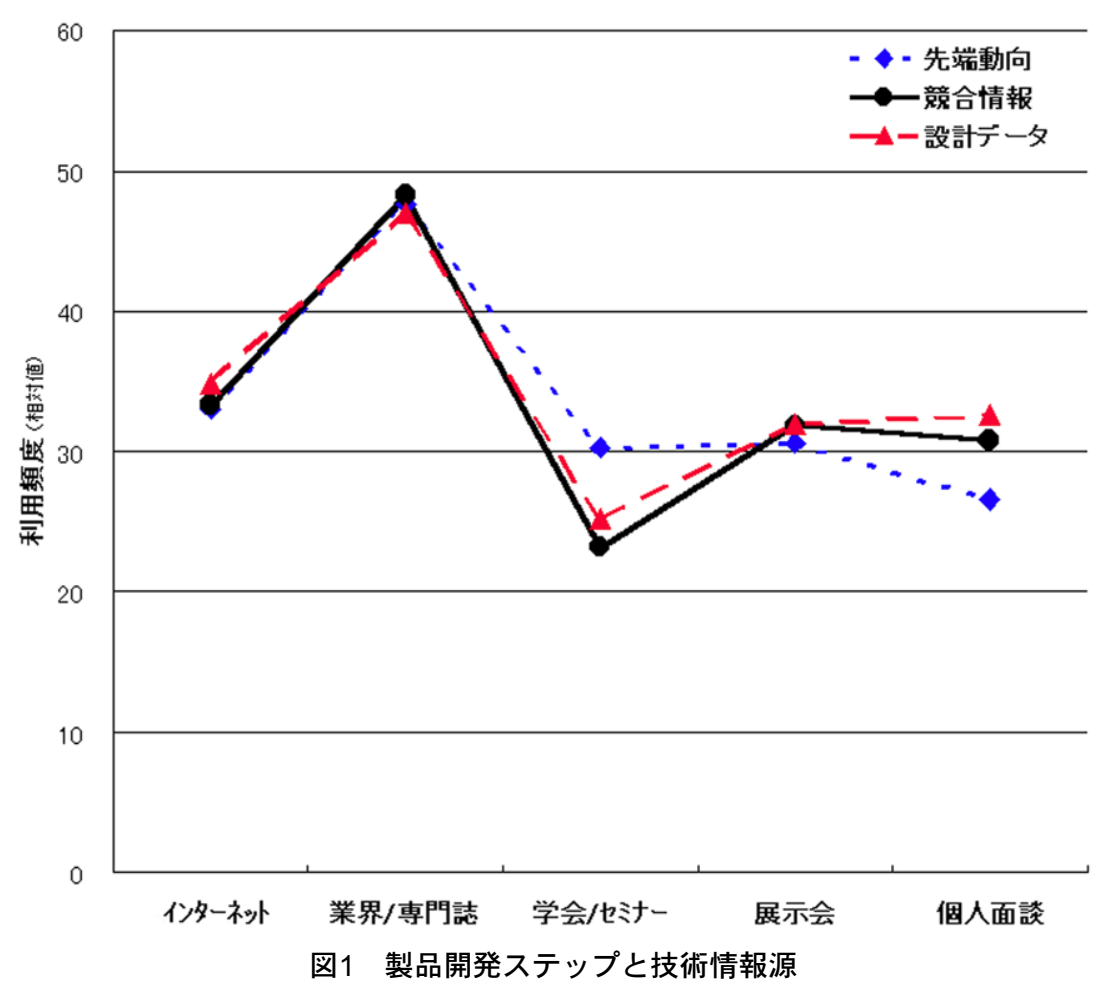




\section{3. 分析・計測機器メーカの技術情報 サービス}

分析・計測機器は研究者や技術者に使っていただ く専門性の高い商品である。以前は, メーカが性能 の高い製品を提供すれば, 分析技術に精通したお客 様が目的に合わせて使いこなされていた。ちょう ど, F1カーレーサーのように。

しかし, 技術が進歩し, 専門の分化が進んだ今日, 単にハードウエアを販売するだけでは不十分であ る。優れた機器を使って望む成果を出していただく ための仕掛け作りが重要になっている。これを支援 するのが「お客様指向」の技術情報サービスである。

図2はホリバの技術情報サービスの仕組みであ る。

従来は, まず会社案内で概要を紹介し, 興味を持 たれた方にカタログで製品の特性を説明し, 購入い ただいたお客様に対して取扱説明書を渡していた。 しかし, この流れは, 特定の製品を購入し, 所定の 機能を使っていただくための，いわば「メーカ指 向」の技術情報サービスであった。

今求められている技術情報サービスは, 製品が生 みだされた技術的・社会的背景や，その製品がお客 様の仕事とどうつながるかを明確にする「お客様指 向」の視点である。

ホリバは, このような視点に立って, 次のような 冊子を発行している。

\section{(1) $\mathrm{ABIROH}$}

本誌は, 科学技術の先端トピックスを当社の製品 概要とともに紹介するもので, 従来の会社案内を技 術面から補足する小冊子である。このほか, 地球環 境に関する科学読み物 “GAIAPRESS” や, 分析技 術に関する入門 “SENSORIUM” などを当社のホー ムページ3で公開して, 文化貢献の一助としている。 (2) 分析アプリケーション集

当社の分析センターが発行する事例集で, 技術者 が新たなサンプルを分析したり, 測定結果を解析す るときに役立つ。本アプリケーション集はCD-ROM 化して有償で販売している。

(3) Readout HORIBA Technical Reports

Readoutは，「ホリバが創造・育成した技術を，広 く世にお知らせし，読み取っていただく」ことを 願って1990年に創刊した「お客様指向」の技術情報 誌である。現在, 年2回発行し, 国内の研究機関や 企業を中心に無償で配布している。

\section{Readoutの編集}

\section{1. 編集方針}

本誌の編集の基本方針は, 今, 話題になっている 課題を特集テーマとして取り上げ, 関連する製品や 技術をお客様にタイムリーにお届けすることであ る。特集テーマが当社のビジネス戦略と緊密に連動 していることは当然である。例えば, 創刊号（1990

\section{お客様}

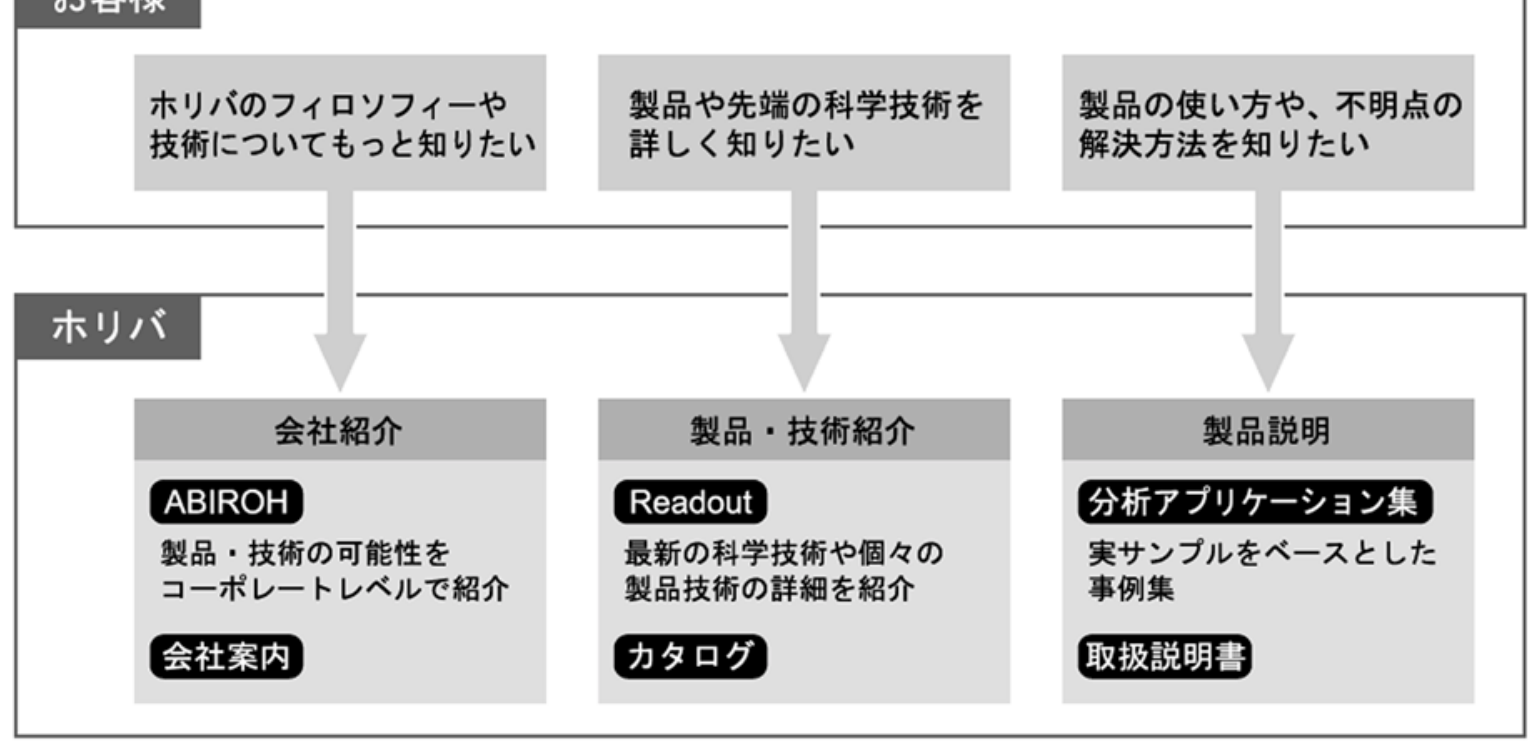

図2 ホリバの技術情報サービスシステム 
年7月) では「地球環境をはかる」を, 最新号 (2001 年9月）はディーゼルエンジンから排出される粒子 状物質に焦点を当てた「PM計測」を特集テーマと した。

\section{2. 掲載記事}

1つの論文に起・承・転・結があるように，技報 にも記事ごとに果たすべき役割（カテゴリ）があ る。設定された特集テーマを基に, カテゴリのつな がりを考えながら記事を構成する。

(1) 巻頭言

巻頭言は当社のビジネスポリシーを技術面から 読み取っていただく，まさにReadoutの顔である。

(2) 科学技術動向

特集テーマに関連する最新の科学技術の動向を, 社内·外の専門家による討論や講演会を通して読み 取っていただく記事である。

(3) 製品論文

各製品の基本原理や特徵, 応用例などの技術的事 項を詳しく記述した技術論文である。近年は, 応用 面の記述をより多くし,ソリューションを提供でき るよう心がけている。

\section{3. 査読}

技術論文はまず正確でなければならない。と同時 に, 計測機器に関連する技術分野は多岐にわたりか つ専門化されている。このため, だれもが分かりや すく表現されていることがまず必要である。また， 技術者は，担当する製品や技術を詳しく知ってもら いたいと願うあまり，ときには知的権利保護の配慮 を欠くことがある。特に, お客様との関わりが多い 応用に関する論文の取り扱いには格段の配慮が必 要となる。当社では, 原著者の所属長, 専門技術 者, 一般技術者, 知的所有権担当者, および編集部 が, 次のような諸点をそれぞれの立場に立って査読 する。

(1) 専門性 : 技術内容が正しく表現されているかを 所属長およびその分野の専門技術者が チェック。

(2)一般性 : 分かりやすく, 一貫した表現になって いるかを非専門技術者がチェック。

(3) 知的権利保護 : 他者の権利侵害および自社ノウ ハウの過剩流出有無を知的所有権担当が チェック。

\section{5. 制作}

IT技術の発達により，技報の制作環境は近年急激 に変化している。当社でも, 執筆依頼をはじめ, 原 稿作成, 編集, 印刷, 別刷りの電子配信まで, すべ ての工程でインターネットやイントラネットをフ ルに活用している。

\section{1. 制作環境}

ビジネス用アプリケーションソフトはマイクロ ソフト社のOfficeが中心で, 現在, 技術系の原稿は, 国内·海外ともに大半がこれを使って作成されてい る。実験データや各種の技術報告書類もこれらのソ フトで作られるケースが多く, 1つの生データを多 面的に活用する（One-source Multi-use）という点か ら,ソフトの共通化は重要である。

近年, 技術雑誌の制作工程すべてを電子化して, 科学技術情報をいち早く世界に発信しようとする 試みが精力的に展開されている。各種のデジタルメ ディアとのデータの共通化が容易なマークアップ 言語XMLや, ページ感覚で電子文書を処理できる Adobe社のPDF fileなどは, 既存の編集工程を抜本的 に変える可能性を持っている。現在, 科学技術振興 事業団では,「科学技術情報・流通総合システムJ$\mathrm{STAGE}^{4)}$ を立ち上げ学協会に提供している。これ らの試みは，技報編集者にとって大きな魅力であ る。デザイン性の向上や, システムの一般企業への 開放など, 今後のさらなる発展を期待している。

\section{2. 読みやすさ}

技報は, コンテンツが充実していると同時に, 読 みやすく親しみが持てることも重要な要素である。 また, 情報が汇濫する今日, 読者が論文内容をすば やく把握できる配慮も重要である。

Readoutでは, 各論文の1ページ目に, タイトル， 論文内容を端的に示すイラスト, 要旨の 3 つの要素 をまとめ, 興味を持たれた読者はさらに本文へと読 み進むように工夫している。一例として, 図3にホ リバの血球計数装置の外部精度管理プログラム （QCSP）を紹介した論文の表紙を示す。

\section{3. 翻訳}

今や, 分析・計測機器の分野では, ニーズ, シー ズいずれも国境はないに等しい。インターネット の普及がこれに拍車をかけている。現在, Readout は日本語をべースに編集しており, 必要に応じて 


\section{小特集論文}

\section{EATURE} ARTICLE

ホリバの血球計数装置の

外部精度管理プログラム：QCSP

Horiba's External Quality Control Support Program for the Automatic Blood Cell Counter : QCSP

\section{宮崎 誠, 山本 成三}

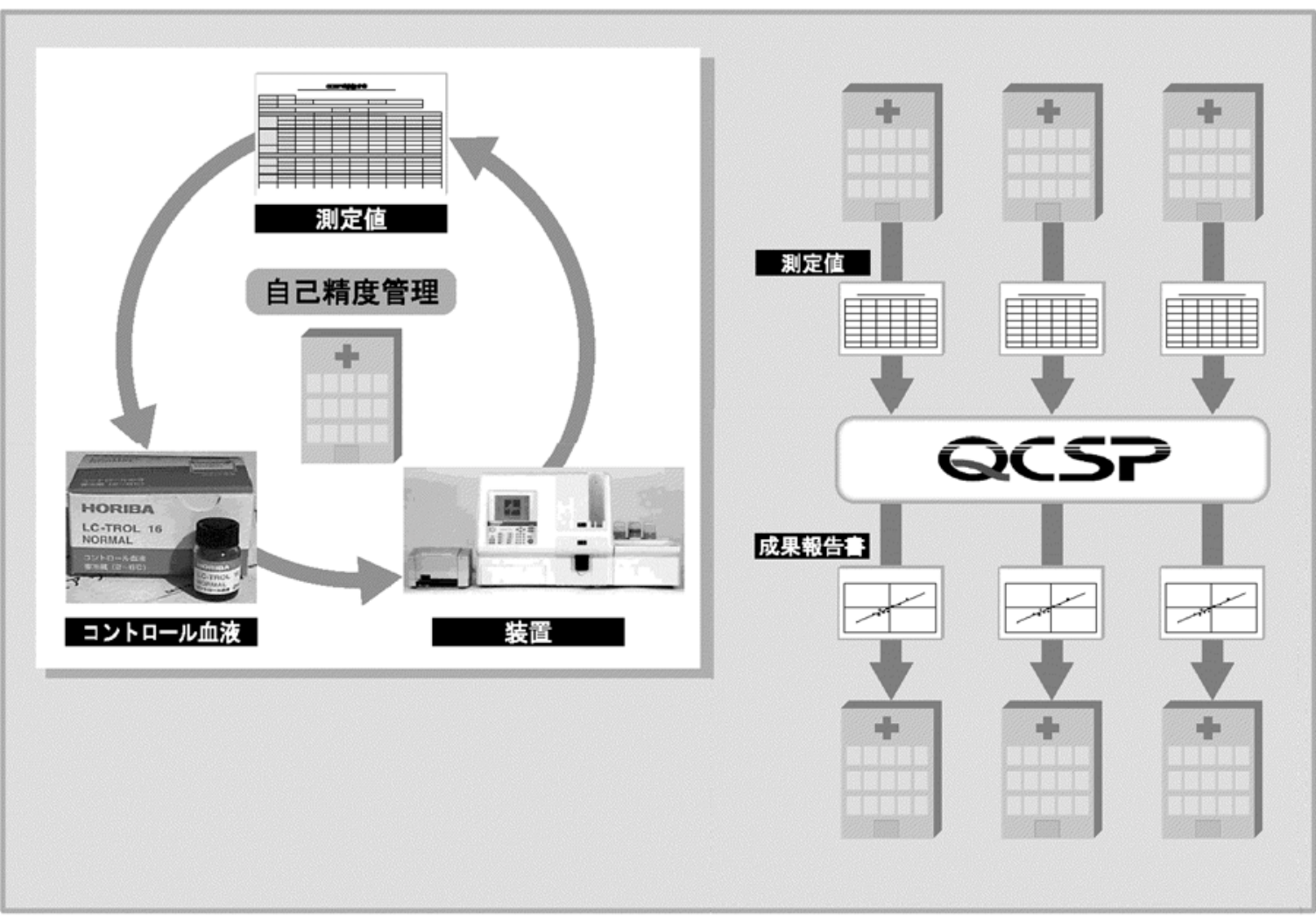

\section{要 旨}

血球計数装置は, 大病院の中央検查室から個人医院まで あらゆる医療施設で, 基本的な臨床検査装置として幅広 く使われている。正しい検查を行うためには, 血球計数装 置の測定精度を常に正しく管理しなければならない。ホ リバは, 当社の自動血球装置LCシリーズをお使いいただ いているお客様に対して, 外部精度管理プログラム (QCSP) サービスを開始した。本稿では, 検体検查装置の 精度管理の考え方, QCSP の概要を紹介寸る。

\section{Abstract}

Automatic blood cell counters are in widespread use as basic clinical examination instruments in medical facilities of all kinds, from central examination rooms of major hospitals to private hospitals. To conduct accurate examinations the measuring accuracy of the counter must be constantly and correctly controlled. Horiba has initiated an Horiba's External Quality Control Support Program (QCSP) for users of its LC Series automatic hematorogy counters. This paper presents the concept behind accuracy control of clinical testing equipment, and an overview of the QCSP. 
英訳版を発行している。最近は, 海外の研究者・技 術者からの寄稿やTV会議システムを使った座談会 なども急増しており, 逆に和訳するケースも少な くない。

グローバル化は単に言語を変えただけでは達成 できない。読者の技術的, 文化的な背景をふまえた 真の包括的な翻訳が求められる5 。 Readoutは, 執筆 者 (発言者), 編集部, 翻訳者 (Native Speaker) が 仮想編集室を作り, 次の諸点に注意をはらいなが ら, 真の翻訳に心がけている。

○可能である限り標準的な英語を使用し, 著しく特 化した用語は避ける

の読者のすべてが英語のネイティブスピーカーで ないことに留意する

○イラスト, 写真, 図表には国際的に認知された記 号や単位を使用する

○著者は自身の社会的, 文化的背景に基づいて執筆 （発言）する傾向があることを前提とする

\section{6. 電子配信}

欲しい情報を, 欲しい形で, スピーディーにお届 けすることが技術情報サービスの基本である。 Readoutは, 冊子の発行に加え, インターネットを 通じて電子配信サービスも行っている。図 4 に Readoutの電子配信システムを示す。

当社のホームページ上の技術情報サイトのをア クセスされた方はHTMLで書かれた概要, および PDF化された全文を閲覧することができる。さら に, 詳しい内容が必要な場合には, インターネット 経由で要求いただくと,オンデマンド・プリントさ れた別刷が関連資料とともに要求者に配送される。 そして, お問い合わせの内容によっては, 原著者や 担当者が直接ご相談させていただき, 適時対応して いる。

一般に, ホームページや雑誌などから得られる情 報は，「入手は容易だが質が十分ではない」と言わ

\section{配信／問合せ}

\section{対応}

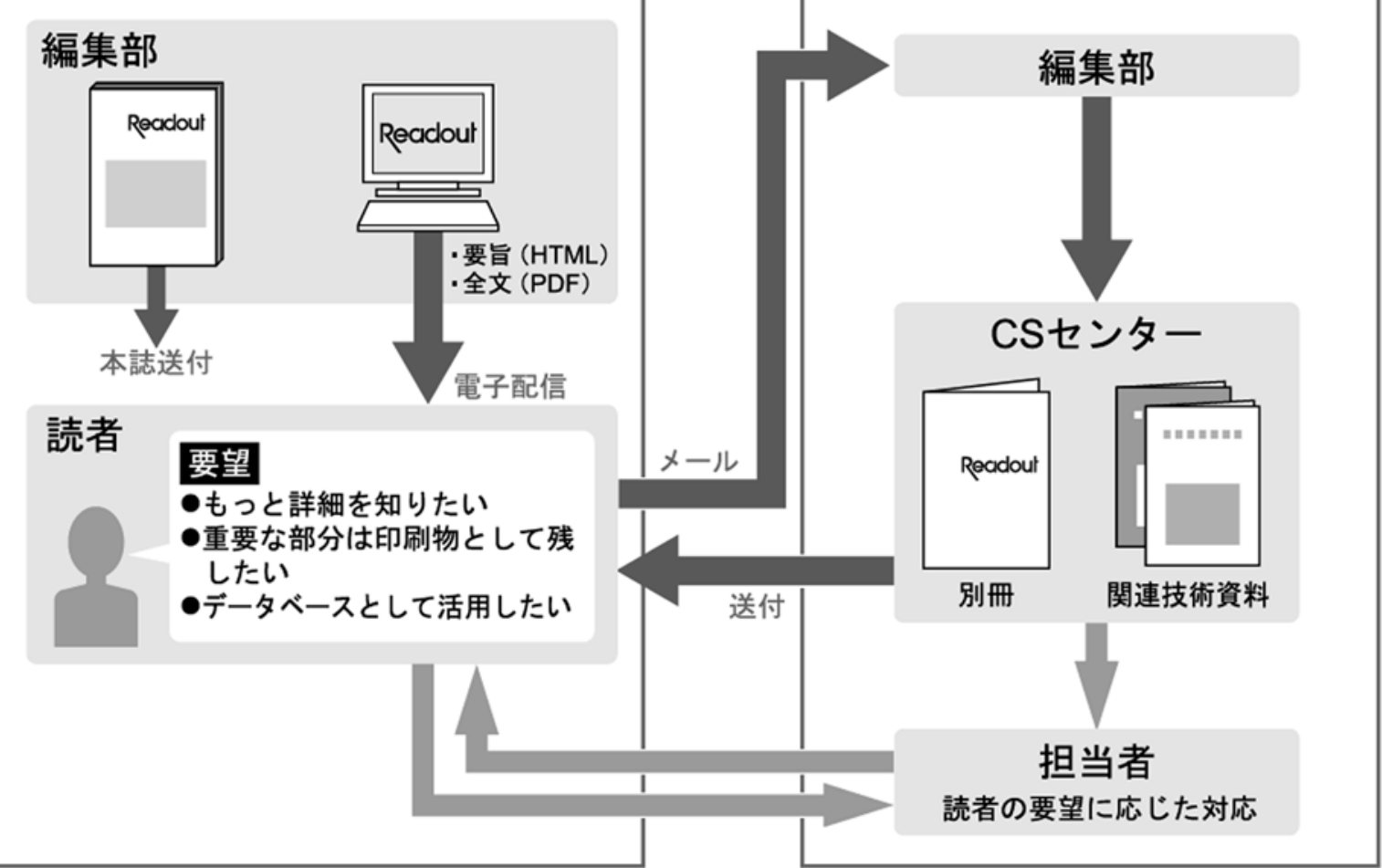

図4Ｒeadoutの電子配信システム 
れているが7, このように, インターネットからface to faceの面談まで, 各種のコミュニケーションメ ディアを上手に組み合わせることにより, 確度の高 いスピーディーな情報交換が可能になる。

\section{7. おわりに}

科学技術が高度化・複雑化し, ビジネスのグロー
バル化・スピード化が加速するなか, 技報が果たす 役割が見直されている。今回, ホリバの技術情報誌 Readoutを通して, お客様指向, 読者指向の技報作 りの取り組みを紹介した。しかし, 技術情報サービ スのニーズ, シーズともに日々刻々変化している。 本稿が,より優れた技術情報誌実現へ向けた論議を 始める1つのトリガーになれば幸いである。

\section{参考文献}

1）田中功. 技報の特徵と利用. 京浜文化. Vol.30, No.2, 1988, p.1-8.

2）中小企業庁. 企業の情報化実態調査. 平成9年度中 小企業白書. 1997, p.393-397.

3) HORIBA. (http://global.horiba.com/), (accessed 200109-18)

4) J-STAGE. (http://www.jstage.jst.go.jp/ja/), (accessed 2001-09-18)
5) McCaleb, B.E., Koch, K.J. and Dwyer, D.E. What it's like to work for a Japanese company. Techniscribe. Vol.10, No.4, 1989, p.5.

6) HORIBA技術情報. (http://global.horiba.com/support/ tech_info/index.htm), (accessed 2001-09-18)

7）機械技術者のための情報収集学. 日経メカニカル. No.530, 1998-11, p.32-51. 